Civilian Radioactive Waste Management System Management \& Operating Contractor

\title{
Range of Neutronic Parameters for Repository Criticality Analyses
}

Document Identifier No.: B00000000-01717-5705-00101 REV 01

September 1999

Prepared for:

U. S. Department of Energy

Yucca Mountain Site Characterization Project Office

P.O. Box 30307

Las Vegas, Nevada 89036-0307

Prepared by:

Civilian Radioactive Waste Management System

Management \& Operating Contractor

1261 Town Center Drive

Las Vegas, Nevada 89144

Under Contract Number

DE-AC08-91RW00134 


\section{Civilian Radioactive Waste Management System Management \& Operating Contractor}

\section{Range of Neutronic Parameters for Repository Criticality Analyses}

\section{Document Identifier No.: B00000000-01717-5705-00101 Revision 01}

October 1999

Prepared by:
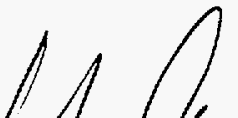

W. J. Anderson, Preparer

Neutronics Methodology

Checked by:

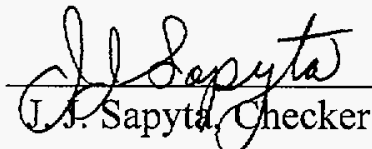

Neutronics Methodology

Approved by:

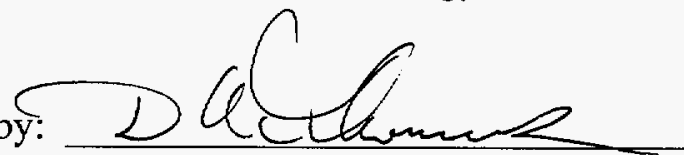

D. A. Thomas, Manager

Neutronics Methodology

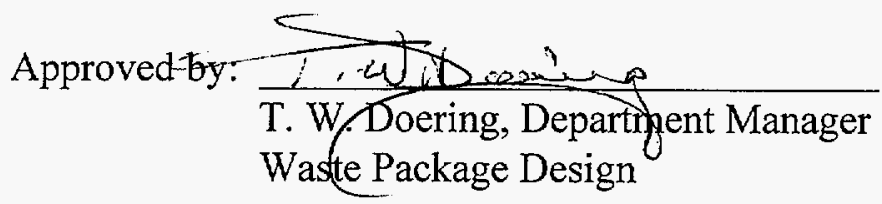

Date: $9 / 27 / 99$

Date: $9 / 27 / 99$

Date: $9 / 28 / 1999$

Date: $9,25,99$ 


\section{HISTORY OF CHANGE PAGE}

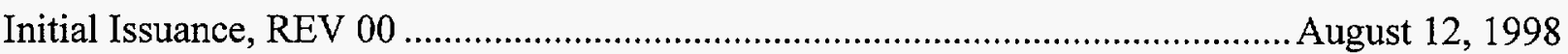

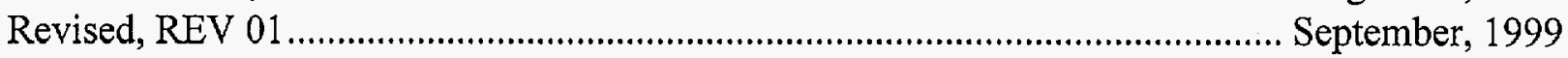

Total Rewrite - Format changes and additional benchmark cases. 


\section{CONTENTS}

Page

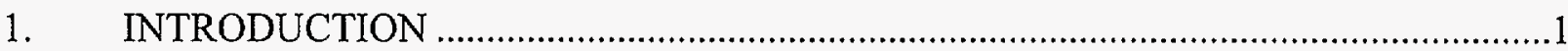

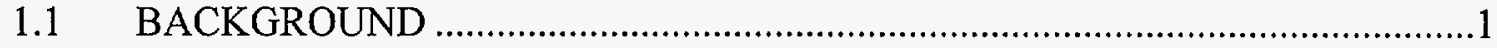

1.2 OBJECTIVE

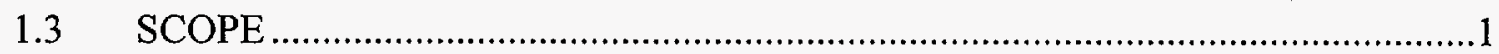

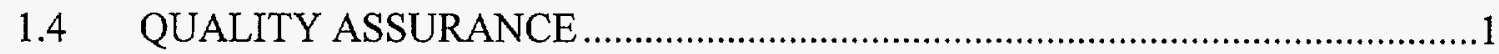

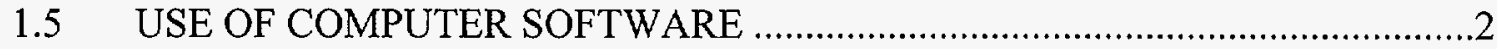

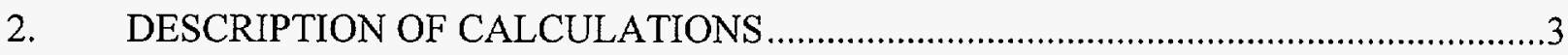

2.1 DESCRIPTION OF HOMOGENEOUS LCES......................................................

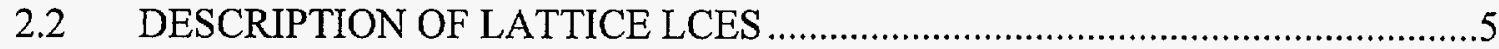

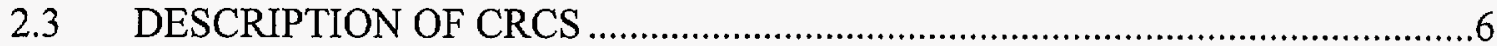

2.4 SUMMARY OF THE BENCHMARK AND REPOSITORY CALCULATIONS11

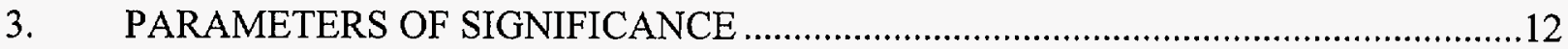

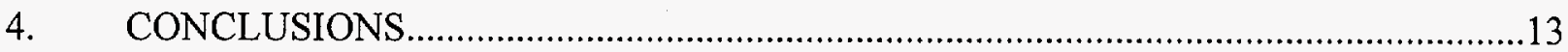

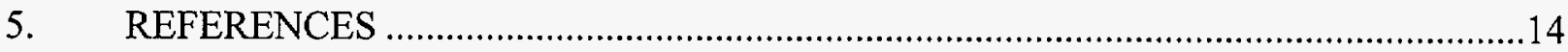




\section{TABLES}

Page

2.1-1. Summary of Homogeneous LCE Characterizations ............................................................. 4

2.2-1. Summary of Lattice LCE Characterizations .................................................................... 6

2.3-1. Commercial Reactor Criticals State Points ………......................................................... 7

2.3-2. Commercial Reactor Criticals Fuel Characterizations ………........................................... 9

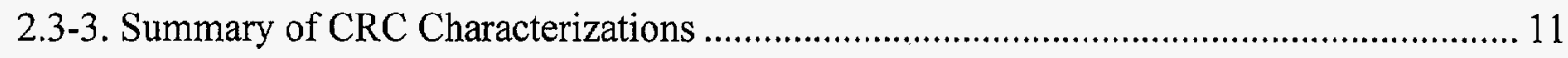

3-1. Benchmarked Range of Parameters For Repository Calculations........................................ 12

\section{FIGURES}

Page

None Used. 


\section{ACRONYMS AND ABBREVIATIONS}

$\begin{array}{ll}\begin{array}{l}\text { AENCF } \\ \text { at\% }\end{array} & \begin{array}{l}\text { Average Energy of a Neutron Causing Fission } \\ \text { Atom Percent }\end{array} \\ \text { CL } \\ \text { CRWMS } & \begin{array}{l}\text { Critical Limits } \\ \text { Commercial Reactor Criticals } \\ \text { Civilian Radioactive Waste Management System }\end{array} \\ \text { DOE } & \text { U.S. Department of Energy } \\ \text { EFPD } & \text { Effective Full Power Days } \\ k_{\text {eff }} & \text { k-effective } \\ \text { LCE } & \text { Laboratory Critical Experiments } \\ \text { M\&O } & \text { Management and Operating Contractor } \\ \text { MGR } & \text { Monitored Geologic Repository } \\ \text { NRC } & \text { U.S. Nuclear Regulatory Commission } \\ \text { OCRWM } & \text { Office of Civilian Radioactive Waste Management } \\ \text { PWR } & \text { Pressurized Water Reactor } \\ \text { QA } & \text { Quality Assurance } \\ \text { Weight Percent } & \end{array}$




\section{INTRODUCTION}

The Range of Neutronic Parameters for Repository Criticality Analyses technical report contains a summary of the benchmark criticality analyses (including the laboratory critical experiment [LCEs] and the commercial reactor criticals [CRCs]) used to support the validation of the criticality evaluation methods. This report also documents the development of the Critical Limits (CLs) for the repository criticality analyses.

\subsection{BACKGROUND}

The United States Department of Energy (DOE) Office of Civilian Radioactive Waste Management (OCRWM) is developing a methodology for criticality analysis to support disposal of commercial spent nuclear fuel in a geologic repository. A topical report (DOE OCRWM 1998a) on the disposal criticality analysis methodology was submitted to the United States Nuclear Regulatory Commission (NRC) for formal review. The following discussion provides a summary of the benchmark criticality analyses to establish a "range of applicability" (ROA) for parameters important to the criticality analyses. This discussion also documents the development of the CLs for the repository criticality analyses. This report supports the development of the disposal criticality analysis methodology.

\subsection{OBJECTIVE}

The objective of this report is to establish the ROA over selected parameters. The results of this will support the development and validation of the disposal criticality analysis methodology.

\subsection{SCOPE}

The scope of this report includes the following benchmark analyses:

- LCE Homogeneous Mixture Criticals

- LCE Lattice Criticals

- Pressurized Water Reactor (PWR) CRCs

Additional types of critical experiments may be added in revisions to this report.

\subsection{QUALITY ASSURANCE}

The Quality Assurance (QA) program applies to the development of this report. The data provided in this report will indirectly be used to develop the methodology for evaluating the Monitored Geologic Repository (MGR) waste package and engineered barrier segment. The QAP-2-3 (Classification of Permanent Items) evaluation entitled Classification of the Preliminary MGDS Repository Design (CRWMS M\&O 1999a) has identified the waste package as a MGR item important to radiological safety and waste isolation. The Waste Package Operations manager has evaluated the technical document development activity in accordance with QAP-2-0, Conduct of Activities. The QAP-2-0 activity evaluation, Neutronics Methodology - SR (CRWMS M\&O 1999b), has determined that the preparation and review of this technical document is subject to Quality Assurance Requirements and Description (DOE OCRWM 1998b) requirements. As specified in NLP-3-18, Documentation of QA Controls on Drawings, Specifications, Design Analyses, and Technical Documents, this activity is subject to QA controls. 
As documented in the Range of Neutronic Parameters Calculation File (CRWMS M\&O 1999c, pp. 20-54), the source information is taken from published reports and a handbook on benchmark experiments (Organization for Economic Cooperation and Development-Nuclear Energy Agency (OECD-NEA) 1998). Most of the LCEs are taken from OECD-NEA 1998, which is a standard handbook, generally accepted by the scientific and engineering community. OECD-NEA 1998 is used in a number of license applications and validation reports through out the nuclear industry. The data in this reference is therefore considered "Accepted Data".

As noted in Table 5-1 of CRWMS M\&O 1999c, all of the CRCs and the remainder of the LCEs are taken from various industry and national laboratory reports. Information regarding the $\mathrm{CRCs}$ and LCEs specified in Table 5-1 of CRWMS M\&O 1999c should be considered to be verified (TBV) in that the specified references are not considered accepted data sources per the retroactive procedural requirement of AP-SIII.2Q initiated by the July 27, 1999 issuance of the DOE Letter, "Accepted Data Call", from R.E. Spence to J.L. Younker (DOE 1999).

\subsection{USE OF COMPUTER SOFTWARE}

No scientific and engineering software or computational software was used in the development of this report. 


\section{DESCRIPTION OF CALCULATIONS}

This section provides a summary of the analyzed systems used to generate the supporting analytic results reported in this document. The following subsections include summaries of the characterizations of the analyses. CRWMS M\&O 1999c (pp. 20-61) documents the characterization data reported in Section 2.

CRWMS M\&O 1999d provides additional information for the original set of 338 LCEs. These are the LCEs referenced in the Disposal Criticality Analysis Methodology Topical Report (DOE OCRWM 1998a).

\subsection{DESCRIPTION OF HOMOGENEOUS LCES}

The LCEs presented in this section represent solutions and solid systems containing uranium, plutonium, or both uranium and plutonium. All of the LCEs in this section are fresh fuel experiments. CRWMS M\&O 1999c (pp. 23-40) characterizes these LCE configurations.

Calling this group of experiments "homogeneous" is a misnomer. Most of the experiments are homogeneous, but the set also includes a number of arrays. Some of these arrays are multiple tanks of the same solution, and some are "piles" of uranium, polyethylene, and paraffin cubes in various configurations. The name "Homogeneous LCEs" is a carryover from the original issuance (REV 00) of CRWMS M\&O 1997 and is maintained for consistency between the reports. The term "Homogeneous LCEs" is used in the rest of this document to represent the entire set listed above.

The following list is a breakdown of the "Homogeneous LCEs". Included in the list, in parentheses, is the number of experiments that fit into the given category. The terminology of "Thermal", "Intermediate", and "Fast" systems do not use the traditional definitions of these terms. These are based on the average energy of the neutrons causing fission (AENCF), and were selected for the purposes of trending (CRWMS M\&O 1998a, Attachment I).

1) Homogeneous Thermal Systems (253) $[\mathrm{AENCF}=0.0 \mathrm{MeV}$ to $0.1 \mathrm{MeV}]$

a) Mixed plutonium and natural uranium (34)

b) Plutonium (73)

c) High-enriched uranium, ${ }^{235} \mathrm{U}(105)$

d) Intermediate-enriched uranium, ${ }^{235} \mathrm{U}(10)$

e) Low-enriched uranium, ${ }^{235} \mathrm{U}(25)$

f) High-enriched uranium, ${ }^{233} \mathrm{U}(6)$

2) Homogeneous Intermediate Systems (31) $[\mathrm{AENCF}=0.1 \mathrm{MeV}$ to $1.0 \mathrm{MeV}$ ]

a) Intermediate-enriched uranium, ${ }^{235} \mathrm{U}(19)$

b) Low-enriched uranium, ${ }^{235} \mathrm{U}(12)$

3) Homogeneous Fast Systems (47) [AENCF $>1.0 \mathrm{MeV}]$

a) Plutonium (12)

b) High-enriched uranium, ${ }^{235} \mathrm{U}(15)$

c) Intermediate-enriched uranium, ${ }^{235} \mathrm{U}(10)$

d) High-enriched uranium, ${ }^{233} \mathrm{U}(10)$ 
Table 2.1-1 summarizes the characterizations presented in CRWMS M\&O 1999c (pp. 23-40). The table lists the minimum and maximum values for enrichment and AENCF.

Table 2.1-1. Summary of Homogeneous LCE Characterizations

\begin{tabular}{|c|c|c|c|}
\hline Type of System & Parameter & Minimum & Maximum \\
\hline \multicolumn{4}{|c|}{ Homogeneous Thermal Systems (253) } \\
\hline \multirow[t]{3}{*}{ Mixed plutonium and natural uranium (34) } & ${ }^{235} \mathrm{U}$ Enrichment (wt\%) & $0.44 \%$ & $2.29 \%$ \\
\hline & ${ }^{239} \mathrm{Pu}$ Enrichment (wt\%) & $91.10 \%$ & $93.95 \%$ \\
\hline & AENCF $(\mathrm{MeV})$ & 0.0038 & 0.0596 \\
\hline \multirow[t]{2}{*}{ Plutonium (73) } & ${ }^{239} \mathrm{Pu}$ Enrichment (wt\%) & $95.01 \%$ & $99.46 \%$ \\
\hline & AENCF $(\mathrm{MeV})$ & 0.0025 & 0.0481 \\
\hline \multirow[t]{2}{*}{ High-enriched uranium, ${ }^{235} \mathrm{U}(105)$} & ${ }^{235} \mathrm{U}$ Enrichment (wt\%) & $89.04 \%$ & $93.2 \%$ \\
\hline & AENCF $(\mathrm{MeV})$ & 0.0022 & 0.0426 \\
\hline \multirow[t]{2}{*}{ Intermediate-enriched uranium, ${ }^{235} \mathrm{U}(10)$} & ${ }^{235} \mathrm{U}$ Enrichment (wt $\left.\%\right)$ & $29.83 \%$ & $29.83 \%$ \\
\hline & AENCF $(\mathrm{MeV})$ & 0.0455 & 0.0743 \\
\hline \multirow{2}{*}{$\begin{array}{l}\text { Low-enriched uranium, }{ }^{235} \mathrm{U}(25) \\
{[T B V-1370]}\end{array}$} & ${ }^{235} \mathrm{U}$ Enrichment (wt\%) & $4.9 \%$ & $10 \%$ \\
\hline & AENCF (MeV) & 0.0114 & 0.0523 \\
\hline \multirow[t]{2}{*}{ High-enriched uranium, ${ }^{233} \mathrm{U}(6)$} & ${ }^{233} \mathrm{U}$ Enrichment (wt\%) & $97.67 \%$ & $99.70 \%$ \\
\hline & AENCF (MeV) & 0.0030 & 0.0374 \\
\hline \multicolumn{4}{|l|}{ Homogeneous Intermediate Systems (31) } \\
\hline \multirow[t]{2}{*}{ Intermediate-enriched uranium, ${ }^{235} \mathrm{U}(19)$} & ${ }^{235} \mathrm{U}$ Enrichment (wt\%) & $29.83 \%$ & $29.83 \%$ \\
\hline & AENCF (MeV) & 0.1041 & 0.2168 \\
\hline \multirow{2}{*}{$\begin{array}{l}\text { Low-enriched uranium, }{ }^{235} \mathrm{U}(12) \\
{[T B V-1366]}\end{array}$} & ${ }^{235} \mathrm{U}$ Enrichment (wt\%) & $1.01 \%$ & $1.16 \%$ \\
\hline & AENCF $(\mathrm{MeV})$ & 0.1549 & 0.2541 \\
\hline \multicolumn{4}{|c|}{ Homogeneous Fast Systems $(47)$} \\
\hline \multirow[t]{2}{*}{ Plutonium (12) } & ${ }^{239} \mathrm{Pu}$ Enrichment (at\%) & $88.6 \%$ & $98.2 \%$ \\
\hline & $\mathrm{AENCF}(\mathrm{MeV})$ & 1.4768 & 1.9188 \\
\hline \multirow[t]{2}{*}{ High-enriched uranium, ${ }^{235} \mathrm{U}(15)$} & ${ }^{235} \mathrm{U}$ Enrichment (wt \%) & $90 \%$ & $94 \%$ \\
\hline & AENCF $(\mathrm{MeV})$ & 1.1620 & 1.5979 \\
\hline \multirow[t]{2}{*}{ Intermediate-enriched uranium, ${ }^{235} \mathrm{U}(10)$} & ${ }^{235} \mathrm{U}$ Enrichment (wt $\left.\%\right)$ & $16 \%$ & $55.38 \%$ \\
\hline & AENCF (MeV) & 1.2784 & 1.4403 \\
\hline \multirow[t]{2}{*}{ High-enriched uranium, ${ }^{233} \mathrm{U}(10)$} & ${ }^{233} \mathrm{U}$ Enrichment (wt\%) & $98.13 \%$ & $98.20 \%$ \\
\hline & AENCF $(\mathrm{MeV})$ & 1.5178 & 1.7740 \\
\hline
\end{tabular}




\subsection{DESCRIPTION OF LATTICE LCES}

The LCEs presented in this section represent moderated lattice configurations. The lattice LCEs database is broken down by type of experiment. All of the LCEs in this section are fresh fuel experiments. The LCE lattice configurations are described in CRWMS M\&O 1999c (pp. 38-54).

The following list is a breakdown of the "Lattice LCEs". Included in the list, in parentheses, is the number of experiments that fit into the given category.

1) Lattice Thermal Systems (78) $[\mathrm{AENCF}=0.0 \mathrm{MeV}$ to $0.1 \mathrm{MeV}]$

a) Mixed plutonium and natural uranium fuel pins (3)

b) High-enriched uranium, ${ }^{235} \mathrm{U}$, fuel pins (21)

c) High-enriched uranium, ${ }^{235} \mathrm{U}$, fuel plates (23)

d) High-enriched uranium, ${ }^{235} \mathrm{U}$, cruciform fuel rods (28)

e) Intermediate-enriched uranium, ${ }^{235} \mathrm{U}$, fuel pins (2)

f) Low-enriched uranium, ${ }^{235} \mathrm{U}$, fuel pins (1)

2) Lattice Intermediate Systems (95) $[\mathrm{AENCF}=0.1 \mathrm{MeV}$ to $1.0 \mathrm{MeV}]$

a) Mixed plutonium and natural uranium fuel pins (22)

b) High-enriched uranium, ${ }^{235} \mathrm{U}$, fuel pins (5)

c) Low-enriched uranium, ${ }^{235} \mathrm{U}(68)$

Table 2.2-1 summarizes the characterizations presented in CRWMS M\&O 1999c (pp. 38-54). The table lists the minimum and maximum values for enrichment and $\mathrm{AENCF}$. 
Table 2.2-1. Summary of Lattice LCE Characterizations

\begin{tabular}{|c|c|c|c|}
\hline Type of System & Parameter & Minimum & Maximum \\
\hline \multicolumn{4}{|c|}{ Lattice Thermal Systems (78) } \\
\hline \multirow{3}{*}{$\begin{array}{l}\text { Mixed plutonium and natural uranium fuel } \\
\text { pins (3) } \\
{[T B V-1368, T B V-1371]}\end{array}$} & ${ }^{235} \mathrm{U}$ Enrichment (wt\%) & $0.71 \%$ & $0.71 \%$ \\
\hline & ${ }^{239} \mathrm{Pu}$ Enrichment (wt\%) & $86.15 \%$ & $90.61 \%$ \\
\hline & AENCF $(\mathrm{MeV})$ & 0.0609 & 0.0819 \\
\hline \multirow[t]{2}{*}{ High-enriched uranium, ${ }^{235} \mathrm{U}$, fuel pins (21) } & ${ }^{235} \mathrm{U}$ Enrichment (wt $\left.\%\right)$ & $62.40 \%$ & $62.40 \%$ \\
\hline & AENCF $(\mathrm{MeV})$ & 0.0229 & 0.0799 \\
\hline \multirow{2}{*}{$\begin{array}{l}\text { High-enriched uranium, }{ }^{23} \mathrm{U} \text {, fuel plates } \\
\text { (23) }\end{array}$} & ${ }^{235} \mathrm{U}$ Enrichment (wt\%) & $93.17 \%$ & $93.17 \%$ \\
\hline & AENCF $(\mathrm{MeV})$ & 0.0097 & 0.0147 \\
\hline \multirow{2}{*}{$\begin{array}{l}\text { High-enriched uranium, }{ }^{235} \mathrm{U} \text {, cruciform fuel } \\
\text { rods (28) }\end{array}$} & ${ }^{235} \mathrm{U}$ Enrichment (wt\%) & $80 \%$ & $90 \%$ \\
\hline & AENCF $(\mathrm{MeV})$ & 0.0106 & 0.0919 \\
\hline \multirow{2}{*}{$\begin{array}{l}\text { Intermediate-enriched uranium, }{ }^{235} \mathrm{U} \text {, fuel } \\
\text { pins (2) }[T B V-1369]\end{array}$} & ${ }^{235} \mathrm{U}$ Enrichment (wt\%) & $20 \%$ & $20 \%$ \\
\hline & AENCF $(\mathrm{MeV})$ & 0.0236 & 0.0240 \\
\hline \multirow[t]{2}{*}{ Low-enriched uranium, ${ }^{235} \mathrm{U}$, fuel pins (1) } & ${ }^{235} \mathrm{U}$ Enrichment (wt\%) & $5.74 \%$ & $5.74 \%$ \\
\hline & AENCF $(\mathrm{MeV})$ & 0.0886 & 0.0886 \\
\hline \multicolumn{4}{|c|}{ Lattice Intermediate Systems (95) } \\
\hline \multirow{3}{*}{$\begin{array}{l}\text { Mixed plutonium and natural uranium fuel } \\
\text { pins (22) }[T B V-1359, T B V-1366 \\
\qquad T B V-1368, T B V-1371]\end{array}$} & ${ }^{235} \mathrm{U}$ Enrichment (wt\%) & $0.71 \%$ & $0.71 \%$ \\
\hline & ${ }^{239} \mathrm{Pu}$ Enrichment (wt \%) & $86.14 \%$ & $91.84 \%$ \\
\hline & AENCF $(\mathrm{MeV})$ & 0.1015 & 0.3776 \\
\hline \multirow[t]{2}{*}{ High-enriched uranium, ${ }^{235} \mathrm{U}$, fuel pins (5) } & ${ }^{235} \mathrm{U}$ Enrichment (wt\%) & $96 \%$ & $96 \%$ \\
\hline & AENCF $(\mathrm{MeV})$ & 0.2376 & 0.2422 \\
\hline \multirow{2}{*}{$\begin{array}{l}\text { Low-enriched uranium, }{ }^{235} \mathrm{U} \text {, fuel pins (68) } \\
{[T B V-1357, T B V-1358, T B V-1359} \\
T B V-1360, T B V-1361, T B V-1362 \\
T B V-1363, T B V-1364, T B V-1365 \\
T B V-1367, T B V-1368]\end{array}$} & ${ }^{235} \mathrm{U}$ Enrichment (wt\%) & $1.15 \%$ & $5.74 \%$ \\
\hline & AENCF $(\mathrm{MeV})$ & 0.1025 & 0.4085 \\
\hline
\end{tabular}

\subsection{DESCRIPTION OF CRCs}

The CRCs discussed in this section represent forty-five PWR critical state points. All of the fuel is initially low enriched uranium oxide. The state points relate to various "burnup" points for various cycles in six different reactors as shown in Table 2.3-1 and Table 2.3-2. The CRC configurations are described in CRWMS M\&O 1999c (pp. 55-64) and are summarized in Table 2.3-3. All of the 
values presented in Section 2.3 are considered "to be verified" (TBV-1349).

(Note: EFPD = Effective Full Power Days)

Table 2.3-1. Commercial Reactor Criticals State Points

\begin{tabular}{|c|c|c|c|}
\hline State Point & Reactor & Cycle & $\begin{array}{c}\text { Time of Measurement } \\
\text { EFPD }\end{array}$ \\
\hline 1 & Crystal River, Unit \#3 & $1 \mathrm{a}$ & 0.0 \\
\hline 2 & Crystal River, Unit \#3 & $1 b$ & 268.8 \\
\hline 3 & Crystal River, Unit \#3 & $1 b$ & 411.0 \\
\hline 4 & Crystal River, Unit \#3 & 2 & 0.0 \\
\hline 5 & Crystal River, Unit \#3 & 3 & 0.0 \\
\hline 6 & Crystal River, Unit \#3 & 3 & 168.5 \\
\hline 7 & Crystal River, Unit \#3 & 3 & 250.0 \\
\hline 8 & Crystal River, Unit \#3 & 4 & 0.0 \\
\hline 9 & Crystal River, Unit \#3 & 4 & 228.1 \\
\hline 10 & Crystal River, Unit \#3 & 4 & 253.0 \\
\hline 11 & Crystal River, Unit \#3 & 5 & 0.0 \\
\hline 12 & Crystal River, Unit \#3 & 5 & 388.5 \\
\hline 13 & Crystal River, Unit \#3 & 6 & 0.0 \\
\hline 14 & Crystal River, Unit \#3 & 6 & 96.0 \\
\hline 15 & Crystal River, Unit \#3 & 6 & 400.0 \\
\hline 16 & Crystal River, Unit \#3 & 7 & 0.0 \\
\hline 17 & Crystal River, Unit \#3 & 7 & 260.3 \\
\hline 18 & Crystal River, Unit \#3 & 7 & 291.0 \\
\hline 19 & Crystal River, Unit \#3 & 7 & 319.0 \\
\hline 20 & Crystal River, Unit \#3 & 7 & 462.3 \\
\hline 21 & Crystal River, Unit \#3 & 7 & 479.0 \\
\hline 22 & Crystal River, Unit \#3 & 8 & 0.0 \\
\hline 23 & Crystal River, Unit \#3 & 8 & 97.6 \\
\hline 24 & Crystal River, Unit \#3 & 8 & 139.8 \\
\hline 25 & Crystal River, Unit \#3 & 8 & 404.0 \\
\hline
\end{tabular}


Table 2.3-1. Commercial Reactor Criticals State Points

\begin{tabular}{|c|c|c|c|}
\hline State Point & Reactor & Cycle & $\begin{array}{c}\text { Time of Measurement } \\
\text { EFPD }\end{array}$ \\
\hline 26 & Crystal River, Unit \#3 & 8 & 409.6 \\
\hline 27 & Crystal River, Unit \#3 & 8 & 515.5 \\
\hline 28 & Crystal River, Unit \#3 & 9 & 0.0 \\
\hline 29 & Crystal River, Unit \#3 & 9 & 158.8 \\
\hline 30 & Crystal River, Unit \#3 & 9 & 219.0 \\
\hline 31 & Crystal River, Unit \#3 & 9 & 363.1 \\
\hline 32 & Crystal River, Unit \#3 & 10 & 0.0 \\
\hline 33 & Crystal River, Unit \#3 & 10 & 573.7 \\
\hline 36 & Sequoyah, Unit \#2 & 1 & 0.0 \\
\hline 37 & Sequoyah, Unit \#2 & 3 & 0.0 \\
\hline 38 & Sequoyah, Unit \#2 & 3 & 210.9 \\
\hline 46 & McGuire, Unit \#1 & 1 & 0.0 \\
\hline 47 & McGuire, Unit \#1 & 6 & 0.0 \\
\hline 48 & McGuire, Unit \#1 & 6 & 62.4 \\
\hline 49 & McGuire, Unit \#1 & 7 & 0.0 \\
\hline 50 & McGuire, Unit \#1 & 7 & 129.0 \\
\hline 51 & McGuire, Unit \#1 & 7 & 282.3 \\
\hline 59 & Three Mile Island, Unit \#1 & 1 & 0.0 \\
\hline 60 & Three Mile Island, Unit \#1 & 5 & 0.0 \\
\hline 61 & Three Mile Island, Unit \#1 & 5 & 114.4 \\
\hline
\end{tabular}


Table 2.3-2. Commercial Reactor Criticals Fuel Characterizations

\begin{tabular}{|c|c|c|c|c|}
\hline \multirow{2}{*}{ State Point } & \multirow{2}{*}{$\begin{array}{l}\text { Initial Enrichment } \\
\left(w t \%{ }^{235} U\right)\end{array}$} & \multicolumn{3}{|c|}{ Burnup (GWd/MTU) } \\
\hline & & Minimum & Maximum & Core Average \\
\hline 1 & 2.445 & 0 & 0 & 0 \\
\hline 2 & 2.446 & 4 & 11 & 8 \\
\hline 3 & 2.446 & 7 & 16 & 12 \\
\hline 4 & 2.670 & 0 & 17 & 9 \\
\hline 5 & 2.693 & 0 & 20 & 8 \\
\hline 6 & 2.693 & 3 & 25 & 13 \\
\hline 7 & 2.693 & 4 & 28 & 15 \\
\hline 8 & 2.648 & 0 & 18 & 7 \\
\hline 9 & 2.648 & 6 & 25 & 14 \\
\hline 10 & 2.648 & 7 & 26 & 15 \\
\hline 11 & 2.915 & 0 & 17 & 7 \\
\hline 12 & 2.915 & 9 & 28 & 19 \\
\hline 13 & 3.210 & 0 & 22 & 12 \\
\hline 14 & 3.210 & 3 & 25 & 15 \\
\hline 15 & 3.210 & 13 & 35 & 24 \\
\hline 16 & 3.554 & 0 & 25 & 10 \\
\hline 17 & 3.554 & 6 & 33 & 18 \\
\hline 18 & 3.554 & 7 & 34 & 19 \\
\hline 19 & 3.554 & 8 & 35 & 20 \\
\hline 20 & 3.554 & 11 & 39 & 24 \\
\hline 21 & 3.554 & 12 & 40 & 25 \\
\hline 22 & 3.755 & 0 & 31 & 12 \\
\hline 23 & 3.755 & 3 & 32 & 15 \\
\hline 24 & 3.755 & 4 & 33 & 17 \\
\hline 25 & 3.755 & 11 & 36 & 25 \\
\hline 26 & 3.755 & 11 & 36 & 25 \\
\hline 27 & 3.755 & 14 & 39 & 28 \\
\hline
\end{tabular}


Table 2.3-2. Commercial Reactor Criticals Fuel Characterizations

\begin{tabular}{|c|c|c|c|c|}
\hline \multirow{2}{*}{ State Point } & \multirow{2}{*}{$\begin{array}{c}\text { Initial Enrichment } \\
\left.\mathbf{( w t} \%{ }^{\mathbf{2 3 5}} \mathbf{U}\right)\end{array}$} & \multicolumn{3}{|c|}{ Burnup (GWd/MTU) } \\
\cline { 3 - 5 } & 3.892 & Minimum & Maximum & Core Average \\
\hline $\mathbf{2 8}$ & 3.892 & 5 & 35 & 14 \\
\hline $\mathbf{2 9}$ & 3.892 & 7 & 37 & 19 \\
\hline $\mathbf{3 0}$ & 3.892 & 11 & 37 & 21 \\
\hline $\mathbf{3 1}$ & 4.015 & 0 & 30 & 25 \\
\hline $\mathbf{3 2}$ & 4.015 & 18 & 49 & 15 \\
\hline $\mathbf{3 3}$ & 2.535 & 0 & 0 & 33 \\
\hline $\mathbf{3 6}$ & 3.427 & 0 & 27 & 0 \\
\hline $\mathbf{3 7}$ & 3.427 & 7 & 34 & 11 \\
\hline $\mathbf{3 8}$ & 2.602 & 0 & 0 & 19 \\
\hline $\mathbf{4 6}$ & 3.472 & 0 & 28 & 0 \\
\hline $\mathbf{4 7}$ & 3.472 & 2 & 31 & 12 \\
\hline $\mathbf{4 8}$ & 3.618 & 0 & 27 & 11 \\
\hline $\mathbf{4 9}$ & 3.618 & 4 & 32 & 16 \\
\hline $\mathbf{5 0}$ & 3.618 & 9 & 38 & 23 \\
\hline $\mathbf{5 1}$ & 2.633 & 0 & 0 & 0 \\
\hline $\mathbf{5 9}$ & 2.820 & 0 & 25 & 10 \\
\hline $\mathbf{6 0}$ & 2.820 & 2 & 28 & 14 \\
\hline $\mathbf{6 1}$ & & & & \\
\hline & & 0 & 35 & 14 \\
\hline
\end{tabular}


Table 2.3-3. Summary of CRC Characterizations

\begin{tabular}{|l|c|c|}
\hline \multicolumn{1}{|c|}{ Parameter } & Minimum & Maximum \\
\hline Initial Enrichment $\left(\mathrm{wt} \%{ }^{235} \mathrm{U}\right)$ & $2.445 \%$ & $4.015 \%$ \\
\hline Burnup - Minimum $(\mathrm{GWd} / \mathrm{MTU})$ & 0 & 18 \\
\hline Burnup - Maximum $(\mathrm{GWd} / \mathrm{MTU})$ & 0 & 49 \\
\hline Burnup - Core Averaged (GWd/MTU) & 0 & 33 \\
\hline AENCF (MeV) & 0.2344 & 0.2660 \\
\hline
\end{tabular}

\subsection{SUMMARY OF THE BENCHMARK AND REPOSITORY CALCULATIONS}

A complete list of expected repository values is not available at this time. No comparison can be made between the expected repository values and the benchmarked values. This comparison needs to be considered in future, waste form specific, validation reports. 


\section{PARAMETERS OF SIGNIFICANCE}

This section investigates the range of applicability for select parameters. These parameters are chosen because of their effect on reactivity. Table 3-1 lists the benchmarked range of parameters. This is a summary of the information listed in the tables presented previously. These values are considered "to be verified". Any use of these values must carry the assigned "TBV" tracking number as identified in the previous sections.

Table 3-1. Benchmarked Range of Parameters For Repository Calculations

\begin{tabular}{|l|c|c|}
\hline \multicolumn{1}{|c|}{ Parameter } & Minimum & Maximum \\
\hline $\begin{array}{l}\text { Uranium Enrichment for Homogeneous } \\
\text { Calculations (wt } \%{ }^{235} \mathrm{U} \text { ) }\end{array}$ & $0.44 \%$ & $94 \%$ \\
\hline $\begin{array}{l}\text { Plutonium Enrichment for Homogeneous } \\
\text { Calculations (wt } \%{ }^{239} \mathrm{Pu} \text { ) }\end{array}$ & $88.6 \%$ & $99.46 \%$ \\
\hline $\begin{array}{l}\text { Uranium Enrichment for Lattices } \\
\text { (wt } \%{ }^{235} \mathrm{U} \text { ) }\end{array}$ & $0.71 \%$ & $96 \%$ \\
\hline $\begin{array}{l}\text { Plutonium Enrichment for Lattices } \\
\left.\text { (wt } \%{ }^{239} \mathrm{Pu}\right)\end{array}$ & $86.14 \%$ & $91.84 \%$ \\
\hline Initial Enrichment for CRC (wt $\left.\%{ }^{235} \mathrm{U}\right)$ & $2.445 \%$ & $4.015 \%$ \\
\hline Core Average Burnup (GWd/MTU) & 0.0 & 33.06 \\
\hline Assembly Burnup (GWd/MTU) & 0.0 & 49.2 \\
\hline AENCF (MeV) & 0.0022 & 1.9188 \\
\hline
\end{tabular}

To establish CLs, and ultimately the Ranges of Applicability (ROA), for the repository calculations, the multiplication factor $\mathrm{k}_{\text {eff }}$ can be trended on several neutronic parameters to obtain a bias trend related to one of the candidate parameters. CRWMS M\&O 1998a offers examples of CL development. However, these are only for the purposes of example. The real CLs for each waste form will be based on benchmark results that are directly applicable to the waste form. These will likely be covered in the waste form specific validation reports.

The ROA is a combination of the benchmarked range and the trended range. In many cases the ROA, the benchmarked range, and the trended range will be identical. However, a trend may not be applicable over the entire benchmarked range, possibly due to the scarcity of benchmarks at one end of the benchmarked range. In such an instance, the ROA will be smaller than the benchmarked range, and will be more similar to the trended range. 


\section{CONCLUSIONS}

This document presents an approach to developing a Range of Applicability for the MGR criticality analyses. It is not a validation of the codes or methods for any specific waste form or waste package. The specific waste forms/packages will be addressed in future validation reports, which will be submitted as part of the License Application for the MGR.

Although this document establishes specific benchmarked ranges for the parameters, this does not limit the repository to only materials that fall in these ranges. Calculations for criticality analyses may include values outside of these ranges, but the reports evaluating these future repository calculations must include a justification for why the calculations are validated. If a repository waste is outside of the defined range of applicability, additional margin or uncertainty may be needed to ensure subcriticality. The alternative is to add benchmark critical data that covers the extended range and calculate a revised critical limit.

Extension of the range of applicability should be based on trends in the bias as a function of system parameters and, if the extension is large, should be confirmed by alternate means. There is no available guidance on what constitutes a large extension, nor any guidance on how to extend trends in the bias. In all cases, extension of the bias and uncertainty requires the determination and understanding of the trends in the bias and uncertainty. If this extension is made, a detailed justification of the need for an extension, along with a thorough description of the method and procedure used to estimate the bias and uncertainty in this extended range shall be documented and approved.

The data reported herein that are not identified with TBV are acceptable for quality affecting activities. TBV data specified in Section 2 will require the release of the assigned TBV prior to its use in quality affecting activities or in analyses affecting procurement, construction, or fabrication. These TBVs include TBV-1349 and TBV-1357 through TBV-1370

This report is a revision of a first of a kind report. The only differences between this revision and the initial issuance are the inclusion of additional benchmark calculations and updated report formatting. There are no other similar documents existing for the MGR project. 


\section{REFERENCES}

Civilian Radioactive Waste Management System (CRWMS) Management and Operating Contractor (M\&O) 1997. MCNP Evaluation of Laboratory Critical Experiments: Homogeneous Mixture Criticals. BBA000000-01717-0200-00045 REV 00. Las Vegas, Nevada: CRWMS M\&O. ACC: MOL.19971230.0134.

CRWMS M\&O 1998a. Calculation of Subcritical Limits for Nuclear Criticality in a Repository. B00000000-01717-0210-00027 REV 00. Las Vegas, Nevada: CRWMS M\&O. ACC: MOL.19980729.0420.

CRWMS M\&O 1999a. Classification of the Preliminary MGDS Repository Design. B00000000-01717-0200-00134 REV 01. Las Vegas, Nevada: CRWMS M\&O. ACC: MOL.19981103.0546.

CRWMS M\&O 1999b. QAP-2-0 Activity Evaluation, Neutronics Methodology - SR. Las Vegas, Nevada: CRWMS M\&O. ACC: MOL.19990318.0037.

CRWMS M\&O 1999c. Range of Neutronic Parameters Calculation File. B00000000-017170200-00028 REV 01C. Las Vegas, Nevada: CRWMS M\&O. ACC: MOL.19990923.0231

CRWMS M\&O 1999d. Laboratory Critical Experiment Reactivity Calculations. B0000000001717-0210-00018 REV 01. Las Vegas, Nevada: CRWMS M\&O. ACC: MOL.19990526.0294.

DOE 1999. DOE Letter “Accepted Data Call”, from R. E. Spence to J. L. Younker, July 27, 1999. North Las Vegas, Nevada: DOE OCRWM Yucca Mountain Site Characterization Office. ACC: MOL.19990811.0170

DOE OCRWM 1998a. Disposal Criticality Analysis Methodology Topical Report. YMP/TR004Q, Revision 0. Las Vegas, Nevada: DOE OCRWM. ACC: MOL.19990308.0035.

DOE OCRWM 1998b. Quality Assurance Requirements and Description. DOE/RW-0333P, REV 8. Washington, D.C.: DOE OCRWM. ACC: MOL.19980601.0022.

Organization for Economic Cooperation and Development-Nuclear Energy Agency (OECDNEA) 1998. International Handbook of Evaluated Criticality Safety Benchmark Experiments. NEA/NSC/DOC(95)03, September 1998 Edition. Paris, France: Nuclear Energy Agency. TIC: 243013 